Secondary publication on the edoc server of the Humboldt-Universität zu Berlin

https://doi.org/10.18452/21581

This is an Accepted Manuscript of an article published by Taylor \& Francis in Local Environment on 15/06/2016, available online: http://www.tandfonline.com/10.1080/13549839.2016.1195799

Originally published as:

\begin{abstract}
Timothy Moss, Matthias Naumann \& Katharina Krause (2017) Turning wastewater into energy: challenges of reconfiguring regional infrastructures in the Berlin-Brandenburg region, Local Environment, 22:3, 269-285, DOI: 10.1080/13549839.2016.1195799
\end{abstract}

\title{
Turning Wastewater into Energy: Challenges of Reconfiguring Regional Infrastructures in the Berlin-Brandenburg Region
}

\author{
Timothy $\operatorname{Moss}^{a}$, Matthias Naumann ${ }^{a}$, Katharina Krause ${ }^{a}$ \\ ${ }^{a}$ Leibniz Institute for Research on Society and Space (IRS), Erkner, Germany \\ This work was supported by the German Federal Ministry of Education and Research
}

Acknowledgements: (BMBF) under Grant No. 033L025K. 


\section{Turning Wastewater into Energy: Challenges of Reconfiguring Regional 2 Infrastructures in the Berlin-Brandenburg Region}

Abstract

Issues of connectivity between different infrastructure sectors have received surprisingly little attention in recent research. Despite huge interest in issues of sectoral integration surrounding the water-energy nexus, researchers have rarely considered what this might mean for the coupling of infrastructure systems for water/wastewater and energy services. Consequently, the implications of greater connectivity for the governance and socio-spatial constitution of infrastructures are largely unexplored. This paper addresses this research gap with a case study of an attempt to use treated wastewater to produce biomass for energy on degraded land in the Berlin-Brandenburg region of Germany. It takes water reuse for energy crop production as an exemplar of work at the water-energy nexus in order to explore the institutional, spatial and physical dimensions involved in connecting two infrastructure systems to this end. It argues that cross-sectoral integration reaches far beyond issues of technological compatibility, revealing often hidden but crucial differences in the institutional and spatial configuration of energy and wastewater systems. On the basis of a comparative analysis of the institutional arrangements of the region's wastewater and energy systems together with an empirical study of initiatives to use treated wastewater to grow energy crops the paper draws conclusions, firstly, on the potential and limitations of this particular exemplar and, secondly, on the broader implications of the case for understanding institutional challenges of cross-sectoral connectivity on the one hand and prospects for reconfiguring infrastructural relations between cities and rural areas on the other.

Keywords: water-energy nexus; Germany; Berlin-Brandenburg; infrastructure; institutions

Word-count: 7630

\section{Introduction: Integrating Infrastructure Systems}

Different infrastructure systems have always been dependent on each other to some degree. A water supply system simply cannot operate without electricity; coal-fired power plants need water as a coolant; all infrastructure systems are increasingly reliant on modern 
1 telecommunications networks. Issues of connectivity and comparability between different

2 infrastructure sectors have, however, received surprisingly little attention in policy and research circles. Where addressed at all, the interest of infrastructure managers tends to be limited to ways of improving the efficiency or meeting regulatory requirements of a specific sector, such as how to save energy in treating wastewater or how to lower the temperature of cooling water (Olsson 2012). Initiatives to explore innovative ways of interlinking different infrastructure systems for multiple societal benefits are, by contrast, rare (Hansman et al. 2006, Broto and Bulkeley 2013). Similarly, research into the social and spatial dimensions of reconfiguring infrastructure systems has made huge conceptual, methodological as well as empirical, advances in understanding the transition dynamics and path dependencies of individual infrastructure systems, notably in the energy sector (Geels et al. 2016), but little work has been done either in comparing transitions across sectors or in exploring areas of connectivity between two or more sectors and their implications for the governance and socio-spatial constitution of infrastructures (Zimmermann 2001, Konrad et al. 2008). This paper addresses the second of these two scholarly challenges with a case study of an ongoing attempt to use treated wastewater to produce biomass for energy on degraded land in the Berlin-Brandenburg region of Germany.

The paper explores the diverse physical, spatial and institutional dimensions involved in connecting two infrastructure systems. It addresses thereby the materiality of wastewater disposal and energy supply as well as their place-based embeddedness and modes of governance. We argue that initiatives to develop the water-energy nexus (cf. Hussey and Pittock 2012) reach far beyond issues of technological compatibility or resource flow management, revealing often hidden but crucial differences in the institutional make-up of energy and wastewater systems, as well as challenges in connecting areas of urban resource consumption and rural resource transformation. In this paper we use a case study of attempts to promote water reuse for energy production to investigate the role of infrastructures in promoting or obstructing this cross-sectoral ambition and the relative significance of physical, spatial and institutional drivers and constraints. The following questions guide the analysis: 1) What are the principal drivers of interest in water reuse in the region and beyond? 2) In what ways does water reuse for biomass production require a reconfiguration of the region's water and energy infrastructures and how far is this a limiting factor to its application? 3) How far do the empirical findings from the study region resonate with the emergent literature on the governance of water reuse? 4) What are the implications of the findings for the spatial and infrastructural organisation of water-energy nexus practices? 
1 To answer these questions we first analyse the literatures on the governance of the water-energy nexus and water reuse, highlighting the key constraints identified. The following empirical section introduces the research project on which the paper is based ${ }^{1}$, describes the context of water reuse for energy in the study region and presents the key findings on the drivers and constraints of water reuse from an infrastructural perspective. The paper concludes with lessons to be drawn from the case in terms of infrastructure integration, urban-rural relations, institutional coherence and political support.

Interlinking Water and Energy Infrastructure in Theory and Practice: A Critical

\section{Literature Review}

\section{The Water-Energy Nexus}

Recent years have witnessed transformations in both the water and the energy sector which have been orientated largely towards security of supply and environmental sustainability. Water scarcity on the one hand and increasing energy consumption coupled with concerns over climate change on the other appear to be the most urgent problems and principal drivers of change for the two sectors respectively (Olsson 2012). In terms of physical processes, energy and water are closely connected: "Indeed, water mixes with just about every form of energy that human society has hitherto harnessed" (Williams et al. 2014, p. 3). Pumping, processing, distribution and treatment of both freshwater and wastewater consume considerable amounts of energy (King et al. 2013). Conversely, the energy sector has one of the highest levels of water use of any sector of the economy (Carter 2010, Olsson 2012). The extraction and refining of fuels as well the generation and distribution of electricity from both traditional and renewable energy sources can require vast amounts of water, though this is disputed in the literature. While some point to the high level of water use involved in biomass production (Gerbens-Leenes et al. 2009, Gheewala et al. 2011), others demonstrate how effective water management can substantially mitigate the effect on groundwater recharge (Schmidt-Walter and Lamersdorf 2012).

However, in terms of policy processes, these two sectors are largely treated in isolation from each other (Scott et al. 2011). Sector-biased planning approaches have been identified in various

\footnotetext{
1 "Development of integrated land management through sustainable water and resource use in North-East Germany (ELaN)", funded by the German Federal Ministry of Education and Research (BMBF) within the funding priority "Sustainable Land Management".
} 
contexts as major challenges to sustainable transitions (World Economic Forum 2009, Wang not dated). Particularly the shortcomings of local climate mitigation and adaption policies in considering cross-sectorial implications have been critically discussed in recent years (Hussey and Pittock 2012). Bringing water into the equation of carbon sequestration (Pittcock 2011), thermal energy storage (Bonte et al. 2011) and certain forms of renewable energy production such as energy crops, biofuels or hydropower schemes (Dalla Marta et al. 2011, Gheewala et al. 2011, Mo and Zhang 2013, Murphy and Allan 2011, Hardy et al. 2012) has led to a reevaluation of their effectiveness and sustainability. Conversely, bringing energy into the equation of non-traditional water sources and new technologies like desalination and thermal treatment systems has prompted their critical reassessment (Gleick 1994, Siddiqi and Anadon 2011).

The benefit of a nexus approach that considers the interdependencies between water, energy and, ultimately, climate change ${ }^{2}$ has recently aroused interest in research and policy circles. A number of international organizations like the United Nations and the World Business Council for Sustainable Development have pointed out the importance of policy cohesion and integration of different infrastructure sectors and prompted awareness campaigns (World Economic Forum 2009). Buoyed by this new global discourse on nexus thinking, the expectations are high. Promises are made of 'win-win' situations, in which all stakeholders stand to benefit from integrated action across sectors. Williams et al. (2014) insist, that "a comprehensive understanding of the water-energy nexus (...) necessarily considers coupling at all spatial and political scales, from the technologies and practices of personal hygiene, through geographically and historically specific urban production and consumption infrastructures, to the geopolitics of supranational struggles for control of resources" (p. 7). They argue for an understanding of the water-energy nexus that highlights the technologies and infrastructures "through which the interactions between water and energy are reconfigured" (ibid., p. 20). According to Muller (2015) the nexus paradigm shifts "the focus of water resources management from watersheds to problem-sheds, from what society should do for water to what water can do for society" (p. 689). Benson et al. (2015) define as key features of the nexus paradigm the integration of different policy objectives, orientation towards integrated policy solutions and multi-tiered institutions, operation on multiple scales, implementation of multi-stakeholder platforms and securitisation of resources as guiding principles (p. 762).

Nevertheless, the nexus as well as its governance remain too often "buzz words" (Stein et al. 2014) and questions about the implementation as well as the distinct geography of nexus

\footnotetext{
${ }^{2}$ Other nexus issues involve food (security), bioenergy, land use or irrigation (Benson et al. 2015, p. 759).
} 
1 initiatives remain open or grounded by neoliberal and technocratic politics (Williams et al. 2 2014, p. 15) promoting a "financialisation of nature" (Brand and Wissen 2014). Other critiques claim that the nexus is neither complete nor new (Muller 2015, p. 686) and fails to meet the needs of many key actors, mainly in developing countries (ibid., p. 689). Allouche et al. (2015) see "the lack of engagement with market logic with sub-nexuses and difficulty of integration, disregard of the politics of knowledge in framing it as a global scarcity issue and the limits of optimisation" as key shortcomings in nexus thinking (p. 615). Taking water into account when supplying energy, and vice versa, is only one side of the coin. Pursuing a strategy of greater policy coherence with links across different policy levels and sectors is quite another (Scott et al. 2011). How can two - or even more - sectors be successfully integrated and synergies fully exploited? As Hussey and Pittock (2012) emphasize, "the energy sector, the water sector, and - more recently - the climate sector are highly developed within themselves, but only limited effort is made to account for, and manage, the links between them" (p. 2).

Research interest, so far, has concentrated on the constraining dynamics between the two sectors, rather than on the synergy effects or potential of cross-sectoral governance and policy making (Wang, not dated). But what then are the main constraints? Hussey and Pittock (2012) have identified three dimensions:

- First, there is a "lack of accurate, fine-scaled, site-specific data as a major impediment to comprehensive analysis and thus to informed decision-making" (ibid., p. 3) in the management of water and energy resources.

- Second, legislation regulating the relationship between the sectors is inconsistent and fragmented. Key agencies and sectors are not integrated and there is no ongoing crosssectoral problem evaluation or multi-level governance framework (Scott et al. 2011).

- Third, the entrenched separation of the sectors works like a "natural" boundary to integration beyond the policy-making sector, affecting also the social science research community.

Stein et al. (2014) propose a strategic action perspective and pragmatic action on the governance of the nexus because "a key challenge for the nexus is governance, i.e. who decides what issues are addressed when and, above all, how" (p. 4). It entails also dimensions of social equity and environmental justice (Scott et al. 2011, p. 6628, Middelton et al. 2015). Decentralised and democratised decision-making can contribute to solutions as well as to an understanding of challenges connected to the nexus approach (Allouche et al. 2015, p. 621). The governance of the nexus can also be linked to debates on "governance by experiment" (Bos and Brown 2012), 
1 for instance addressing socio-technical or strategic experiments with nexus initiatives

2 (Bulkeley and Broto 2012).

3 Scholarly interest in the water-energy nexus has, until recently, concentrated on operational questions of resource coupling and input-output relationships (Scott et al. 2011, Perrone et al. 2011). While the environmental dimension has been well covered, research on the institutional arrangements and policy dimensions to the water-energy nexus is very scattered, making the need for empirical studies urgent and pivotal (Kenway et al. 2011, p. 1987). In this context it is important to consider that water-energy nexus concerns embrace a broad range of thematic fields as depicted above. Thus, differentiation is needed in more than one sense. In order to understand the constraints and potential of integrated nexus approaches, we have to consider various dimensions in any case study: notably the sectors involved, the scale and scope of the relevant organisational entities, the institutional framework and the material infrastructure. The next section focuses on one component of the water-energy nexus: water reuse.

\section{Water Reuse}

The use of treated wastewater - or water reuse, as it is commonly termed - is widely seen as a way to meet the challenges of increasing water and resource scarcity. The prime motive is to maintain agricultural production whilst relieving pressure on groundwater and surface water resources by recycling used water (see for an overview Lazarova and Bahri 2005). Irrigating food and non-food crops with treated wastewater is considered a promising way of enabling food and livelihood security in the face of the anticipated sharp increase in global demand for agricultural produce (Hamilton et al. 2007). Wastewater can also be used as a substitute for industrial water demand, e.g. as cooling water (Ergas et al. 2006), and as a valuable source of phosphorus (Ludwig 2009), especially given that fossil phosphorus reserves could be exhausted within just 50 years' time "if the world were to replace 10 percent of its energy requirements with energy crops" (Hoff 2011, p. 10). Interest is also directed at producing biogas from wastewater treatment processes as a stable source of energy (Stillwell et al. 2010, Chai Wong 2011). As these few examples suggest, water reuse is particularly dependent on a nexus approach to resource management, requiring the use of land when used for irrigation and frequently connected with the production, as well as the use, of energy.

There are multiple forms of water reuse worldwide, mostly to be found in regions that have, or expect to have, imbalances between water supply and demand (Barnes 2014, Hamilton et al. 2007). Water reuse is also found in 'water-rich' regions, where sanitary or environmental concerns are driving forces (Angelakis and Bontoux 2001, Bixio et al. 2006, Hamilton et al. 
2007, Van der Bruggen 2010). In the European context, water reuse projects have developed rapidly in the last 20 years (European Commission 2015), but at very different rates in different regions. The pressure for alternative water resource solutions is very high in some southern European countries, resulting in multiple projects (e.g. crop and golf course irrigation) and strong advocacy for cohesive water reuse legislation at the European level (Angelakis not dated). By contrast, in the north there exist only a very few small-scale water reuse projects, driven largely by environmental groups (Van der Bruggen 2010, p. 56). The urgency to develop standards and incentives for water reuse is emphasised in the Commission's report "A Water Blueprint for Europe" as one of two "gaps" in the EU's legislation on water management (European Commission 2012), reiterated in an updated analysis of the status quo and prospects for reform (European Commission 2015).

Despite the growing interest in the multiple potential functions of water reuse its application in Europe is currently limited by various challenges and uncertainties. Beyond technical and material limitations the obstacles to implementation can, according to the literature, be categorised into a) acceptance problems, b) institutional problems and c) economic concerns. Re a): Concerns about public health and, to a lesser extent, environmental protection strongly influence public acceptance and, consequently, the implementation and success of water reuse projects. Whilst acceptance depends on the form of reuse, Po et al. (2004) show that concerns diminish when awareness and knowledge increases and residents are able to make an "informed choice" (p. 20) (see also Dolnicar et al. 2011). In line with this, Bixio et al. (2006) also emphasise the importance of awareness and knowledge generation to counterbalance the "emotive" (p. 98) revulsions towards water reuse for lay people.

Re b): In terms of institutional issues, Bixio et al. (2006) have identified three main obstacles to effective and safe water reuse. Firstly, stakeholders have little awareness of the potential of water reuse. In the absence of interdisciplinary understanding water reuse is often excluded from water management scenarios. Secondly, there is often a lack of cooperation among stakeholders mainly due to the absence of institutional arrangements on water cycle management in general and water reuse in particular. Thirdly, one of the major problems for many regions and countries is insufficient guidelines and criteria for reclamation and reuse of water, sometimes impeding projects before they have even started. Where there are no criteria, public officers from regulatory agencies have to rely on their assumptions and are more likely to reject a project due to concern for their own position. Thus, " $[\mathrm{t}]$ here is $[\ldots]$ a controversy between the defenders of strict water quality standards for an absolute protection of public health and the defenders of a pragmatic stance recognizing existing wastewater reuse practices 
and promoting non-potable water uses with less restrictive water quality" (Angelakis et al. 2 1999, p. 2201).

3 Re c): Besides the lack of a regulatory framework, economic and financial concerns are considered a major barrier to water reuse. Implementation and operation costs may vary between individual projects depending on scope, scale and local contexts. The insecurities for local actors regarding the economic efficiency of water reuse projects call for the development of cost-benefit analysis tools - including monetary and non-monetary aspects - and financial support to dispel concerns and create incentives for water reuse projects (Miller 2006, Urkiaga et al. 2008).

While the challenges of implementing water reuse are receiving growing attention in the water governance literature, there are currently very few contributions on the interdependencies between water reuse and energy supply (cf. McDonnell 2014). This is the research gap addressed by the following case study on institutional dimensions of the water-energy nexus and the governance challenges involved in trying to integrate water reuse with the production of energy crops.

\section{Water Reuse in North Germany - Empirical Findings from a Case Study in the Berlin- Brandenburg Region}

Unlike many parts of the world, the Berlin-Brandenburg region is not under pressure of diminishing water resources. Securing drinking water supply and agricultural irrigation are currently not major problems for water management. As such, hydrological circumstances do not generally favour the rapid uptake of water reuse technologies and practices. Nevertheless, the region faces a number of water-related challenges which could be addressed by water reuse. Firstly, water reuse is considered potentially valuable to help stabilise the region's water balance, which suffers in some areas from over-abstraction and generally from the effects of global warming. Secondly, the irrigation of biomass crops could, it is argued, contribute to meeting the regional demand for biomass, thereby minimizing conflict over land use. Thirdly, water reuse offers the potential to deal creatively with land suffering from past over-use, such as degraded fenland and former irrigation fields that would benefit from irrigation with treated wastewater. Several ongoing initiatives are exploring the viability and value of reusing water on such land in the region. Having acquired the permission of the region's water regulators, these involve experiments to improve a degraded moor in the Uckermark district in northeast Brandenburg, to promote biodiversity and recreation on a former irrigation field at 
1 Hobrechtsfelde near Berlin and to explore options for using treated wastewater for growing energy crops near the sewage treatment plant at Wansdorf (Schäfer and Kröger 2015) (see Figure 1). In this paper we seek to identify not only the opportunities, but also the limitations to reconfiguring regional infrastructures around water reuse in general, and the use of treated wastewater for producing energy crops in particular. It is a story, basically, of how global ideas for realising the nexus paradigm and reusing water on land translate into practice in specific regional and local contexts of water, land and energy management.

Figure 1: Irrigation of biomass production with treated wastewater in Wansdorf (near Berlin)

[Insert Figure 1 ca. here]

Source: Benjamin Nölting

\section{The Research Context and Approach}

Our study was conducted within the interdisciplinary research project "Development of integrated land management through sustainable water and resource use in North-East Germany (ELaN)", funded by the Federal Ministry of Education and Research between 2011 and 2015. The ELaN project investigated from diverse disciplinary perspectives the prospects for water reuse as a means of promoting more sustainable forms of water and land management in the Berlin-Brandenburg region (www.elan-bb.de). The results of the project have been summarised in reports (Lischeid et al. 2015, Nölting et al. 2015) targeted at different actors of water and land management. While the general aim of ELaN to enhance new ways of water management was restricted by the existing regulatory framework for water reuse in Germany, the project provided a scientifically-founded basis for discussions on the future potential for water reuse in Germany, particularly in view of the European Commission's planned reforms (Lischeid et al. 2015).

Within the ELaN project the authors conducted a sub-project on the implications of water reuse for regional infrastructure systems. The goal of this sub-project was to study wastewater and energy utilities in particular in order to determine their willingness and ability to implement the model solutions developed by ELaN. The sub-project investigated the use of treated wastewater in rural areas and its potential for biomass production in short rotation coppices for the energy supply of cities from an infrastructure perspective. By analysing connectivity between new 
1 forms of energy supply and wastewater disposal it sought to support the reconfiguration of existing regional infrastructures towards more sustainable systems and the reordering of urbanrural relations in the process. Particular interest lay in identifying potential ways forward for more integrated regional infrastructure systems for wastewater and energy in the region.

The methodology of the ELaN sub-project on regional infrastructures was based firstly on a review of the current literature as well as policy documents on water and land management, water and energy infrastructure systems and their transformation in Berlin-Brandenburg (see Naumann and Moss 2012). Secondly, the project undertook an analysis of the existing institutional framework for water and energy infrastructure governance in the region, its limitations as well as its potential for cross-sectoral infrastructure solutions (Naumann 2014). This analysis drew, in addition to document analysis, on a series of semi-structured, qualitative interviews with representatives from local and regional water authorities, wastewater and energy utilities, regional planning agencies, agricultural associations and NGOs. The interviews were conducted according to a guideline of questions relating to the physical, spatial and institutional dimensions of reconfiguring infrastructure systems for water reuse and analysed according the 'qualitative content analysis' method (Mayring 2000). The following section presents the findings from this research in two steps, addressing first the regional context and then the stakeholders' responses to the infrastructural dimensions of water reuse.

\section{Current Challenges for Water and Energy Infrastructures in the Berlin-Brandenburg Region}

Water and energy infrastructure systems, as main constituents of the water-energy nexus, are faced in Berlin-Brandenburg with three concurrent and overlapping challenges, which are not unique to this region but take on very context-specific forms (cf. Hüesker et al. 2011).

Firstly, climate change - although its detailed impacts are uncertain - will have some negative impact on Berlin-Brandenburg's water resources. This includes a decline in precipitation and decreasing groundwater replenishment, increased intensity of rainfall and, owing to increasing temperatures in the summer months, growing demand for water during hot spells (Germer et al. 2011). The consequences of climate change in the region are likely to be spatially and temporally diverse. For instance, large towns will have to cope with heavy rainfall events, while rural areas will need to improve natural retention of runoff (Gemeinsame Landesplanungsabteilung Berlin-Brandenburg 2012). Global debates about the impact of global 
1 change and especially the role of energy systems are also affecting the future development of

2 Brandenburg's energy infrastructure. Brandenburg's "Energy Strategy 2030” (MWE 2012) aims to reduce energy consumption in the region and to extend renewable energy capacity. By $2030 \mathrm{CO}_{2}$ emissions are planned to decrease by 72 percent (compared to 1990). Nevertheless the use of lignite mining for electricity generation is to be continued, despite harsh criticism of the impact of the lignite industry on the environment and human settlements (Klein 2012, p. 10f., Moss et al. 2015).

Secondly, socio-economic change in the region, marked by de-industrialisation and declining population, is leading to serious problems of under-utilisation for existing water and wastewater infrastructures. The Brandenburg Ministry of Rural Development, Environment and Agriculture recently conducted a participative process for defining a new Leitbild for the region's water and wastewater utilities under the auspices of current and future demographic change (Institut Raum \& Energie et al. 2015). Technical, economic and institutional problems caused by declining water demand are confronting many regions in Eastern Germany (Moss 2008) and could especially endanger remote rural areas likely to become victims of “infrastructural peripheralisation” (Naumann and Reichert-Schick 2013). Rising tariffs for drinking water supply and wastewater disposal could well exacerbate this problem and jeopardise further the development potential of so-called shrinking rural regions. Whilst district heating faces several problems emerging from the declining number of households, gas and electricity supply are less sensitive to problems of under-utilisation (Koziol 2008, p. 177). It is, rather, a political objective in Brandenburg to reduce energy consumption. Demographic change is, though, partially responsible for higher energy prices, because fewer customers have to bear the same grid charges (Schiffler and Gansler 2014). Although the economic base of Brandenburg eroded after 1990, the region defines itself still as an "energy region", in which energy utilities such as the Swedish company Vattenfall play a major role in the regional economy (Klein 2012, p. 40f.).

Thirdly, global debates on liberalisation and privatisation have also affected the institutional structure of water management in Berlin-Brandenburg. During the 1990s several municipalities, mostly larger cities, privatised their water utilities. The case of the Berlin Water Company (BWB) is the most prominent example, not only for instances of privatisation, but also for their contestation and reversal (Beveridge et al. 2014). The BWB was partially privatised in 1999. The secretive nature of this process - in which contracts of the privatisation deal were only published after a public referendum - as well as rapidly rising water fees led to 
massive dissatisfaction, public protests and, ultimately, the political decision to re-municipalise

2 the BWB in 2013. Re-municipalisation is occurring also in other German infrastructure sectors, especially in the energy market (Matecki and Schulten 2013). This emergent trend includes the establishment of new municipal or re-municipalised energy utilities, efforts to decentralise energy planning and provision as well as novel forms of civil society involvement (Becker et al. 2012). The installation of new energy facilities for wind farms, biogas plants and solar farms has often provoked local conflicts over the use of land (ibid.). It is indicative that the government of Brandenburg has introduced "acceptance and participation" as one of four pillars to its "Energy Strategy 2030" (MWE 2012).

At first sight these three infrastructural challenges appear to bear little relevance to the waterenergy nexus. Indeed, the public debates surrounding them rarely address issues of infrastructural interaction. However, a closer look reveals how each of the challenges has major consequences for land, water and energy management in the region, but also offers potential for nexus-based solutions.

Climate protection - a key driver behind the region's efforts to transform its energy provision - is having a major impact on water management in Berlin-Brandenburg. The massive extension of renewable energy facilities as planned in Brandenburg's "Energy Strategy 2030" (MWE 2012) is aggravating competition for land use and could also lead to increasing water demand for energy crops. Driven by technological and economic incentives from the federal Renewable Energy Act (EEG), the cultivation of energy crops has sharply increased in recent years at the expense of food crops, but also arable set-aside land. Serious concerns are being raised about the adverse effects of bio-energy generation on local ecosystems and cultural landscapes dependent on adequate surface and groundwater resources (Naturschutzbeirat 2011).

There are, however, a number of potential benefits to be derived from integrated approaches to the management of water and energy infrastructures in general and for water reuse to produce energy crops in particular. First, as a contribution to mitigating climate change, renewable energy sources such as biomass irrigated with treated wastewater can absorb carbon much faster than fossil energy sources and thereby help sustain the region's water resources in the long term. Further examples for directly integrating renewable energies with wastewater infrastructures include the production of biogas from slurry, the installation of solar panels at wastewater treatment plants and the use of waste heat from sewers. Second, decentralised infrastructures are seen by state and municipal authorities as a way to respond to the impact of 
1 demographic change, especially in rural regions (Ministerium für Umwelt, Gesundheit und

2 Verbraucherschutz des Landes Brandenburg 2014, pp. 40f.). Innovative infrastructure systems, including cross-sectoral solutions, could help develop the Brandenburg's profile as a renewable 'energy region'. Third, the trend of re-municipalisation is buoyed by growing interest in crosssectoral synergies between water and energy services and how they can be supported with technological innovations. The ELaN project studied the prospects for such synergies not only within cities in municipal multi-utilities (Stadtwerke) but on a regional scale. How far this potential for regional infrastructure reconfigurations around the water-energy nexus could be put into practice with water reuse in the Berlin-Brandenburg region is addressed in the following section.

\section{Water Reuse in the Berlin-Brandenburg Region: Opportunities, Institutional Obstacles and}

\section{Future Perspectives}

Based on an analysis of existing modes of wastewater and energy governance in the region and expert interviews we first briefly summarise the current regulatory and political setting for water reuse projects in the region. Second we illustrate how this context influenced the implementation of water reuse solutions within the ELaN project. Finally we discuss the prospects for water reuse with respect to current developments in water management and beyond.

\section{a) Existing institutional framework}

Wastewater disposal is a core responsibility of German municipalities. The regulatory framework is set by legislation at the European level, such as the EU Water Framework Directive or directives concerning urban waste water treatment, at the federal level, such as the Water Resources Law (Wasserhaushaltsgesetz), and at the regional level of the Bundesland, such as the Brandenburg Water Law (Brandenburgisches Wassergesetz). The main actors of wastewater treatment and disposal are, however, the over 400 municipalities in Brandenburg (Naumann 2014, p. 55f.). Municipalities are free to mandate their own municipal enterprise (Eigenbetrieb), one of the 80 municipal federations (Zweckverbände) or a private operator for wastewater disposal. The supervision of wastewater utilities is the responsibility of local water authorities (Untere Wasserbehörden), which are part of the public administration of the 14 administrative districts (Landkreise) in Brandenburg. 
1 The governance of the energy sector also involves different scales of regulation. The European

2 Union and its directives on services in the internal market has been a major driver for the 3 liberalisation of European energy markets. The German federal government applies European directives via national regulation, but has also introduced its own Renewable Energy Sources Act (EEG) to promote renewable energies. The Bundesland Brandenburg has formulated its own "Energy Strategy 2030" (MWE 2012) and supports the development of regional energy concepts at the level of administrative districts (Naumann 2014, p. 57f.). At the local level there exist several municipal utilities, as well as energy cooperatives and bio-energy villages (Becker et al. 2012, p. 46ff.).

\section{b) Institutional obstacles}

During the ELaN project a wide range of data on the potential and risks of wastewater reuse, including the institutional limitations for the development of new infrastructure solutions (Moss and Nölting 2014), was collected. The ELaN sub-project on regional infrastructures identified five major difficulties in connecting wastewater and energy infrastructures which crucially limit the take-up of water reuse in the region.

Firstly, the existing institutional and legal framework in Brandenburg strictly prohibits spreading treated wastewater for reasons of groundwater protection. One wastewater utility complained that "many new ideas simply do not fit the existing legal regulations" (interview wastewater utility \# 4). Only small-scale, experimental projects of water reuse are allowed on the basis of an exceptional, limited and temporary permit. If wastewater utilities are only permitted to spread a small percentage of their treated wastewater there is little incentive for the further development of these solutions (interview wastewater utility \# 5). Recently one of the project's experimental plants for wastewater reuse closed following the expiry of the temporary permission (Schwers 2015). The restrictive policy on irrigating treated wastewater and the very cautious practice of local water authorities differ fundamentally from the regulation for the spreading of sewage sludge on agricultural land. The use of sewage sludge as manure for agricultural production is, interestingly, both legal and practised widely within the region. This echoes a principal criticism in the literature that legislation is often inconsistent (see above). Furthermore, for implementing new solutions of wastewater treatment there is a perceived need for a legal framework that permits small-scale, reedbed treatment plants operated by local residents (interview wastewater utility \# 3). 
1 Secondly, there exist major institutional asymmetries between the management of wastewater treatment and of energy supply. Beyond a few multi-utilities in Brandenburg both sectors are strictly separated in the provision of services. There have been only minor attempts at crosssectoral linkages between wastewater and energy utilities, such as solar panels on wastewater treatment plants or the use of sewage gas for energy needs. The political responsibility for each sector is also divided in Brandenburg between the Ministry of Rural Development, Environment and Agriculture (for wastewater disposal) and the Ministry of Economics and European Affairs (for energy), reflecting the critique of institutional fragmentation from the literature. While there are (still) considerable subsidies and other incentives available for renewable energy facilities there is no such programme for innovations in the wastewater sector. The energy transition is not matched by any 'wastewater transition'.

Thirdly, economic incentives for the use of treated wastewater are currently missing. For wastewater utilities cost effectiveness is the most important motive (interview wastewater utility \# 2). If the reuse of treated wastewater could reduce the fees for discharging wastewater then water reuse would become profitable (interview wastewater utility \# 4). In the farming community there is a general fear that the use of treated wastewater could endanger the marketing of their products (interview agriculture \# 1). In other words, there is an urgent need to consider the perspectives, as well as the actors, of agriculture within reconfigurations of regional infrastructure systems.

Fourthly, the aspiration for new urban-rural linkages, mediated by infrastructure systems, runs up against major difficulties. A common approach for managing water and energy infrastructures between the city of Berlin and the surrounding region of Brandenburg is only slowly evolving (Infrastruktur \& Umwelt und Beratungs- und Servicegesellschaft Umwelt 2011, p. 19). Currently the Joint Spatial Planning Department, the common authority for regional planning in the states of Berlin and Brandenburg, is working on a spatial planning concept for energy and climate protection for the Berlin-Brandenburg region. So far, however, there are no plans for an integrated, regional approach to energy and wastewater services serving the region's towns and villages. At the local scale the major challenge revolves around enrolling the different elements of water reuse at one location: i.e. the availability of wastewater, existing pipes, suitable land and demand for biomass (Kröger et al. 2012). This illustrates the complex relationship between cities, as principal sites of wastewater production and energy use, and the countryside, as (potential) sites for the use of treated wastewater and production of energy crops. 
1 Fifthly, public acceptance of the use of treated sewage remains a major challenge, confirming

2 findings from the wider literature (see above). The facilities of the ELaN project for spreading treated wastewater on the fenland site have been damaged several times (Windolff 2012). There is clearly a need, as for renewable energy facilities, to improve acceptance of new forms of wastewater disposal. Until now there has been no broad public debate on a 'wastewater transition' comparable to that on the energy transition in Germany.

c) Future prospects for water reuse in the region

Despite these current limitations, the ELaN project has revealed a number of (emergent) factors working in favour of future water reuse. Being prepared for the political "windows of opportunity" (Kingdon 1995) which these factors may create will be crucial for the future success of water reuse.

Firstly, the international debate on the potential of water reuse is increasingly influencing German water management. The European Commission has targeted water reuse for irrigation or industrial purposes as a key issue in its "Water Blueprint" strategy (European Commission 2012, 2015). Following this policy initiative, the German Federal Environmental Agency is currently conducting a research project on the use of treated wastewater for irrigation in Germany. Furthermore there is an emerging debate about the energy efficiency of wastewater treatment plants and their role as energy providers via biogas (Keil 2013) that is stimulating discussions over possible connections between the wastewater and energy sectors (Schmiedeskamp 2011, Steinigeweg 2012).

Secondly, there is an ongoing debate on nutrients in wastewater in Germany. The Berlin and Brandenburg state governments have launched a political initiative to reduce the nutrient contamination of local water resources (SenStadt and MUGV 2012). The German federal government announced an impending end to the practice of spreading sewage sludge on agricultural land. As a result, alternative forms of wastewater disposal - and especially water recycling - will be needed in the near future in order to meet these new environmental requirements.

Thirdly, the State of Brandenburg already allows some flexibility in adapting existing standards to local requirements (Daedlow et al. 2015). Under the law for "Testing Deviations from the State's Standards in Municipalities in Brandenburg" (Standarderprobungsgesetz) the government of Brandenburg is seeking alternative solutions to cope with the vast challenges of demographic change. The establishment of such solutions involves support for municipalities 
1 in terms of financial resources and know-how (Voß et al. 2011). The Brandenburg Ministry of

2 Rural Development, Environment and Agriculture has published a report to discuss the use of treated wastewater in this context (MUGV 2010b).

4 Fourthly, within the next 10-20 years there will be a fresh round of investment not only in wastewater treatment plants but also in other water infrastructures, such as weirs, drainage systems etc. (interview agriculture \# 1, interview regional planning \# 1, interview wastewater utility \# 1). This need for investment is creating a window of opportunity for considering and implementing forms of wastewater disposal more suited to demographic change and to new water protection and retention requirements.

Finally, the current trend towards re-municipalising water as well as energy utilities, above all in Berlin (Beveridge et al. 2014), could also create opportunities for reconfigured and regionally adapted infrastructure systems. Berlin's city government plans to establish a 'citizen utility' (Bürgerstadtwerk) in order to provide multiple infrastructure services from one municipal company (Moss et al. 2015). The political aim of re-municipalised utilities to develop more sustainable modes of energy provision could also entail amalgamating infrastructure systems currently separated. The termination of concession contracts in the energy sector could enable municipalities to formulate new requirements for network operators, such as greater connectivity to the wastewater sector. Furthermore, municipal enterprises such as housing companies could promote new, connected forms of energy supply and wastewater disposal (Naumann 2014, p. 62).

\section{Conclusion}

“The nexus is a political process, not just a technical one" (Middleton et al. 2015, p. 630)

In this paper we have argued that scholarly as well as policy attention towards integrated infrastructural solutions at the interface between wastewater and energy sectors has been slow to emerge in recent years. Focussing on water reuse and its interactions with energy provision, the paper set out to demonstrate how the water-energy nexus requires reconfiguring infrastructures in a socio-technical sense. This involved investigating the institutional and spatial, as well as the physical, dimensions of (in-)compatibility between water and energy infrastructure systems. In this way the paper has sought to complement existing studies on the water-energy nexus that concentrate primarily on operational or input-output aspects. Using 
an empirical case study of attempts to promote water reuse for energy crop irrigation in Berlin-

2 Brandenburg, we discussed the challenges and opportunities involved in terms of realigning the region's water and energy infrastructures.

In response to the first of our four research questions raised in the introduction, we identified in our literature review compelling arguments for a stronger coupling of the water and energy sectors. Mutual energy and wastewater interdependencies present resource synergies with reciprocal effects ranging from the global to the local scale. One of these relates to reusing water for energy crops. We noted how interest in water reuse is gaining traction in policy and research circles. This is being driven globally by concern over water shortages and pressure on groundwater resources as agricultural production grows and climate change takes effect. In the Berlin-Brandenburg region, by contrast, the drivers of water reuse are not shortages in water supply but the motives of regional stakeholders to explore more sustainable forms of water and land management. Specifically, water utilities are interested in recycling their treated wastewater and the nutrients it contains, land managers are interested in a regular source of nutrient-rich water to grow energy crops and environmentalists are interested in reusing water to improve water-based ecosystems on degraded land.

The realignment of the region's wastewater and energy infrastructures which water reuse requires is, however, posing significant challenges to this venture. In response to our second question we have demonstrated the institutional, spatial and physical factors working against a favourable reconfiguration of these infrastructures. Our analysis revealed how difficulties in physically coupling wastewater and energy infrastructures pose a major challenge for crosssectoral linkages. Using treated wastewater to help energy crops grow requires sewage treatment plants being located close to land unsuitable for food crops where the risk of groundwater pollution is minimal. This combination at any one location is rare. Even on a suitable site, reusing water means refitting or reordering infrastructural facilities, which implies significant investments. Unless there are adequate financial or regulatory incentives it is very unlikely that financial commitments will be made to put this kind of connectivity into practice. Reforms to wastewater disposal regulations, envisaged for sewage sludge in Germany, can, however, shift the playing field and make the case for water reuse more compelling.

Institutionally, closer connectivity between wastewater and energy infrastructures is hampered by the fact that, in the Berlin-Brandenburg region, the two sectors are regulated and managed separately from each other. This is particularly apparent with regard to the pace and framing of infrastructural transitions, which differ hugely between the two. Thus, while there is 
considerable public support for the development of new, decentralised forms of energy supply

2 based on renewable resources, the dominant logic of wastewater treatment in centralised sewage treatment plants and disposal of treated effluent in main rivers remains largely untouched. The debate on the future of Brandenburg's energy provision is currently not linked to a discussion on the transformation of wastewater and other infrastructure systems.

Spatially, the regional experiences presented in this paper have revealed the multi-scalar nature of nexus relationships. These require a reordering and strengthening of urban-rural linkages, including a governance approach that is capable of reaching beyond existing administrative borders. Water, energy and land management are not inherently bound to the territories of municipalities, counties (Landkreise) or Länder, yet most regulations which govern them certainly are. Reshaping the infrastructural relations between the city and the countryside will thus need governance structures and procedures capable of spanning cities and surrounding rural areas as well as encouraging cross-sectoral integration. One example could be the transfer of the model of urban multi-utilities (Stadtwerke) to the regional level (Regionalwerke).

How far do these empirical findings from the Berlin-Brandenburg region resonate with the emergent literature on the governance of water reuse? In response to our third question, we identified various ways in which the constraints on water reuse in the region replicate the challenges and concerns raised by the international literature on both the water-energy nexus and water reuse. We noted inconsistency in the way different wastewater products are regulated, for instance with far more stringent rules applied to the use of treated wastewater than for (untreated) slurry. The institutional fragmentation between water and energy organisations observed in the region also reflects a common criticism in the literature. The same is true of concerns over potential health hazards and risks for marketing agricultural produce grown on land irrigated with treated wastewater. What the case study reveals that is rarely mentioned in the literature, by contrast, is the huge importance of spatial proximity of wastewater production and use, of physical connectivity between energy and wastewater infrastructures, of urban-rural relations and of political will in promoting connected transitions.

This brings us to our concluding remarks, relating to the fourth question on the implications of the findings for the spatial and infrastructural organisation of water-energy nexus practices. We have observed in both the literature review and empirical case study how efforts to link the wastewater and energy sectors are facing major problems of coordination, ranging from disconnected spaces of production and use to deeply engrained ways of sector-biased thinking. It follows that nexus policies relating to infrastructure will have to go far beyond the clarion 
1 call for "integration, integration, integration" (Williams et al. 2014, p. 13). One promising avenue emerging from the analysis is to identify possible interdependencies between transitions in different infrastructural sectors. There are currently very few attempts at cross-sectoral transitions, but the case of water reuse in Berlin-Brandenburg illustrates well the importance of considering the dependency of an energy transition on a wastewater transition. At the same time, the study has revealed how conflictual such infrastructural transitions can be. Water reuse, often presented as a win-win situation for humans and the environment alike, often provokes considerable opposition. This can take the form of consumers fearful of potential public health hazards, environmental regulators concerned at detrimental impacts on groundwater resources and farmers objecting to taking a business risk without adequate security. The local benefits of infrastructural transitions are not equally distributed. This applies to water reuse, where the potential beneficiaries are often not those being asked to pay the initial costs. Not only participation and local acceptance will be crucial issues for future efforts to reconfigure infrastructures, therefore, but also a fair distribution of the costs and benefits. A key issue of future research will be, therefore, to identify the winners and losers of reconfigurations and to negotiate acceptable solutions in a democratic manner: "in a word, to politicise the nexus" (Williams et al. 2014, p. 21).

\section{Acknowledgements}

The authors are grateful to the German Federal Ministry of Education and Research (BMBF) for funding the research on which this paper is based and to members of the ELaN project team for their constructive criticism of our research findings. They would also like to thank the two anonymous reviewers for their valuable suggestions for improving the article.

\section{References}

Allouche, J., Middleton, C., and Gyawali, D., 2015. Technical Veil, Hidden Politics: Interrogating the Power Linkages behind the Nexus. Water Alternatives, 8 (1), 610-626.

Angelakis, A. N., not dated. Water Reycling and Reuse in EU: Necessity and Perspectives for establishing EU Legislation [online]. Available from: http://www.smallwat.org/web/uploads/comunicaciones/keynote_angelakis_andreas.pdf [Accessed 5 March 2015]. 
1 Angelakis, A.N., Marecos do Monte, M.H.F., Bontoux, L., and Asano, T., 1999. The status of

2 wastewater reuse practice in the Mediterranean basin: Need for guidelines. Water Research, 33

3 (10), 2201-2217.

4 Angelakis, A.N. and Bontoux, L., 2001. Wastewater reclamation and reuse in European 5 countries. Water Policy, 3 (1), 47-59.

6 Becker, S., Gailing, L., and Naumann, M., 2012. Neue Energielandschaften - Neue 7 Akteurslandschaften. Eine Bestandsaufnahme im Land Brandenburg. Berlin: Rosa$8 \quad$ Luxemburg-Stiftung.

9 Barnes, J., 2014. Mixing water: The reuse of agricultural drainage water in Egypt. Geoforum, $57,181-191$.

Benson, D., Gain, A.K., and Rouillard, J.J., 2015. Water Governance in a Comparative Perspective: From IWRM to a 'Nexus' Approach. Water Alternatives, 8 (1), 756-773.

Beveridge, R., Hüesker, F., and Naumann, M., 2014. From post-politics to a politics of possibility? Unravelling the privatization of the Berlin Water Company. Geoforum, 51 (1), 6674.

Bixio, D., Thoeye, C., De Koning, J., Joksimovic, D., Savic, D., Wintgens, T., and Melin, T., 2006. Wastewater Reuse in Europe. Desalination, 187, 89-101.

Bos, A. and Brown, R., 2012. Governance experimentation and factors of success in sociotechnical transitions in the urban water sector. Technological Forecasting and Social Change, 79 (7), 1340-1353.

Bonte, M., Stuyfzand, P.J., Hulsmann, A., and Beelen, P.V., 2011. Underground thermal energy storage: environmental risks and policy developments in the Netherlands and European Union. Ecology and Society, 16 (1), 22.

Brand, U. and Wissen, M., 2014. The Financialisation of Nature as Crisis Strategy. Journal für Entwicklungspolitik, 30 (2), 16-45.

Broto, V.C. and Bulkeley, H., 2013. Maintaining Climate Change Experiments: Urban Political Urban and Regional Research, 37 (6), 1934-1948 
1 Bulkeley, H. and Broto, V.C., 2012. Government by experiment? Global cities and the governing of climate change. Transactions of the Institute of British Geographers, 38 (3), 361375.

Carter, N.T., 2010. Energy's Water Demand: Trends, Vulnerabilities, and Management., Washington: Congressional Research Service.

Chai Wong, S., 2011. Tapping the Energy Potential of Municipal Wastewater Treatment: Anaerobic Digestion and Combined Heat and Power in Massachusetts [online]. Available from: http://www.mass.gov/eea/docs/dep/water/priorities/chp-11.pdf [Accessed 5 March 2015].

Daedlow, K., Grundmann, P., Oehlschläger, K., Maaß, O., Moss, T., Nölting, B., Steinhardt, U., and von Bock, C., 2015. Gereinigtes Abwasser in der Landschaft - Ein Orientierungsrahmen für strategische Entscheidungsprozesse. Müncheberg: Leibniz Centre for Agricultural Landscape Research.

Dalla Marta, A., Natali, F., Mancini, M., Ferrise, R., Bindi, M. and Orlandini, S., 2011. Energy and Water Use Related to the Cultivation of Energy Crops: a Case Study in the Tuscany Region. Ecology and Society, 16 (2).

Dolnicar, S., Hurlimann, A., and Grün, B., 2011. What affects public acceptance of recycled and desalinated water? Water Research, 45 (2), 933-943.

Ergas, S.J., Therriault, B.M., and Reckhow, D.A., 2006. Evaluation of Water Reuse Technologies for the Textile Industry. Journal of Environmental Engineering, 132 (3), 315323.

European Commission, 2012. A Blueprint to Safeguard Europe's Water Resources. Brussels: European Commission.

European Commission, 2015. Background document to the public consultation on policy options to optimise water reuse in the EU. Brussels: European Commission.

Geels, F.W., Kern, F., Fuchs, G., Hinderer, N., Kungl, G., Mylan, J., Neukirch, M. and Wassermann, S., 2016. The enactment of socio-technical transition pathways: A reformulated typology and a comparative multi-level analysis of the German and UK low-carbon electricity transitions (1990-2014). Research Policy, 45 (4), 896-913. 
1 Gemeinsame Landesplanungsabteilung Berlin-Brandenburg. 2012. Gemeinsames

2 Raumordnungskonzept. Energie und Klima für Berlin und Brandenburg Teil 2. Endbericht.

3 Berlin/Potsdam.

4 Gerbens-Leenes, P.W., Hoekstra, A.Y. and van der Meer, Th., 2009. The water footprint of energy from biomass: A quantitative assessment and consequence of an increasing share of bioenergy in energy supply. Ecological Economics, 68 (4), 1052-1060.

Germer, S., Kaiser, K., Bens, O. and Hüttl, R., 2011. Water Balance Changes and Responses to Ecosystem and Society in the Berlin-Brandenburg Region. Die Erde, 142 (1-2), 65-95.

Gheewala, S.H., Berndes, G., and Jewitt, G., 2011. The bioenergy and water nexus. Biofuels, Bioproducts \& Biorefining, 5 (4), 353-360.

Gleick, P.H., 1994. Water and Energy. Annual Review of Energy and the Environment, 19, 267299.

Hamilton, A., Stagnitti, F., Xiong, X., Kreidl, S., Benke, K., and Maher, P., 2007. Wastewater irrigation: the state of play. Vadose zone journal, 6 (4), 823-840.

Hansman, R.J., Magee, C., de Neufville, R., Robins, R., and Roos, D., 2006. Research agenda for an integrated approach to infrastructure planning, design and management. International Journal of Critical Infrastructures 2(2/3), 146-159.

Hardy, L., Garrido, A., and Juana, L., 2012. Evaluation of Spain's Water-Energy Nexus. International Journal of Water Resources and Development, 28 (1), 151-170.

Hoff, H., 2011. Understanding the Nexus. Background Paper for the Bonn 2011 Conference: The Water, Energy and Food Security Nexus. Stockholm: Stockholm Environment Institute.

Hüesker, F., Moss, T., and Naumann, M., 2011. Managing Water Infrastructures in the BerlinBrandenburg Region between Climate Change, Economic Restructuring and Commercialisation. Die Erde, 142 (1-2), 187-208.

Hussey, K. and Pittock, J., 2012. The Energy-Water Nexus: Managing the Links between Energy and Water for a Sustainable Future. Ecology and Society, 17(1), 31.

Infrastruktur \& Umwelt; Beratungs- und Servicegesellschaft Umwelt, 2011. Gemeinsames Raumordnungskonzept Energie und Klima für Berlin und Brandenburg. Potsdam/Berlin: Joint Spatial Planning Department of Berlin and Brandenburg. 
1 Institut Raum \& Energie, confideon Unternehmensberatung GmbH and SWKH Rechtsanwälte,

2 2015. Abschlussbericht Leitbild Zukunftsfähige Siedlungswasserwirtschaft Brandenburg.

3 Potsdam: Brandenburg Ministry of Rural Development, Environment and Agriculture.

4 Keil, S., 2013. Die energieautarke Kläranlage. Wunschtraum oder Wirklichkeit. KA-Betriebs5 Info, $43(3), 2103-2107$.

6 Kenway, S.J., Lant, P.A., Priestley, A. and Daniels, P., 2011. The connection between water and energy in cities: a review. Water Science \& Technology, 63 (9), 1983-1990.

8 King, C.W., Stillwell, A.S., Twomey, K.M., and Webber, M.E., 2013. Coherence Between Water and Energy Policies. Natural Resources Journal, 53 (1), 117-215.

Kingdon, J.W., 1995. Agendas, Alternatives, and Public Politics, 2nd ed. New York: Harper Collins.

Klein, D., 2012. Widersprüche in der Brandenburger Energiewende. Horizonte sozialökologischer Transformation. Berlin: Rosa-Luxemburg-Stiftung.

Konrad, K., Truffer, B., and Voß, J.-P., 2008. Multi-regime dynamics in the analysis of sectoral transformation potentials: evidence from German utility sectors. Journal of Cleaner Production, 16 (11), 1190-1202.

Koziol, M., 2008. Räumliche Differenzierung der Infrastrukturversorgung. Chancen und Restriktionen im Rahmen des Stadtumbaus. In: T. Moss, M. Naumann, and M. Wissen, eds. Infrastrukturnetze und Raumentwicklung. Zwischen Universalisierung und Differenzierung. München: oekom, 173-186.

Kröger, M., Rückert-John, J., and Schäfer, M., 2012. Wissensintegration im nachhaltigen Landmanagement. Inter- und transdisziplinäre Problembeschreibung im Projektverbund ELaN. Müncheberg: Leibniz Centre for Agricultural Landscape Research.

Lazarova, V. and Bahri, A., eds., 2005. Water Reuse for Irrigation: Agriculture, Landscapes, and Turf Grass. Boca Raton: CRC Press.

Lischeid, G., ed., 2015. Empfehlungen zum Risiko-basierten Management der Verwendung von gereinigtem Abwasser in der Landschaft. Müncheberg: Leibniz Centre for Agricultural Landscape Research. 
1 Lischeid, G., Schäfer, M., Steinhardt, U., Moss, T., Nölting, B. and Koeppe, P., 2015.

2 Nachhaltiges Landmanagement durch integrierte Wasser- und Stoffnutzung. Kernaussagen des

3 ELaN-Forschungsverbunds. Müncheberg: Leibniz Centre for Agricultural Landscape

4 Research.

5 Ludwig, H., 2009. Rückgewinnung von Phosphor aus der Abwassereinigung. Eine Bestandesaufnahme. Bern: Bundesamt für Umwelt.

7 Matecki, C. and Schulten, T., eds., 2013. Zurück zur öffentlichen Hand? Chancen und 8 Erfahrungen der Rekommunalisierung. Hamburg: VSA.

Mayring, P., 2000. Qualitative Content Analysis. FQS. Forum Qualitative Research, 1 (2), 20.

McDonnell, R.A., 2014. Circulations and transformations of energy and water in Abu Dhabi's hydrosocial cycle. Geoforum, 57, 225-233.

Middleton, C., Allouche, J., Gyawali, D., and Allen, S., 2015. The Rise and Implications of the Water-Energy-Food-Nexus in Southeast Asia through an Environmental Justice Lens. Water Alternatives, 8 (1), 627-654.

Miller, W.G., 2006. Integrated concepts in water reuse: managing global water needs. Desalination, 187 (1-3), 65-75.

Ministerium für Umwelt, Gesundheit und Verbraucherschutz des Landes Brandenburg, 2014. Nachhaltigkeitsstrategie für das Land Brandenburg. Potsdam.

Mo, W. and Zhang, Q., 2013. Energy-nutrients-water nexus: Integrated resource recovery in municipal wastewater treatment plants. Journal of Environmental Management 127, 255-267.

Moss, T., 2008. 'Cold Spots' of Urban Infrastructure: 'Shrinking' Processes in Eastern Germany and the Modern Infrastructural Ideal. International Journal of Urban and Regional Research, 32 (2), 436-451.

Moss, T., Becker, S., and Naumann, M., 2015. Whose energy transition is it, anyway? Organisation and ownership of the Energiewende in villages, cities and regions. Local Environment, 20 (12), 1547-1563.

Moss, T. and Nölting, B., 2014. Institutionen zur Nutzung gereinigtem Abwassers: Anwendungen, Ambivalenzen, Anpassungen. In: T. Moss and B. Nölting, eds. Mehrschichtige Institutionenanalyse zum nachhaltigen Landmanagement. Chancen und Hemmnisse der 
1 Nutzung von gereinigtem Abwasser. Müncheberg: Leibniz Centre for Agricultural Landscape

2 Research, 1-8.

3 MUGV - Brandenburg Ministry of Environment, Health and Consumer Protection, 2010a.

4 Biomassestrategie des Landes Brandenburg. Potsdam: Brandenburg Ministry of Environment, 5 Health and Consumer Protection.

6 MUGV - Brandenburg Ministry of Environment, Health and Consumer Protection, 2010b.

7 Positionspapier Verwendung von gereinigtem Abwasser zur Stabilisierung des

8 Wasserhaushaltes. Potsdam: Brandenburg Ministry of Environment, Health and Consumer 9 Protection.

Muller, M., 2015. The 'Nexus' As a Step Back towards a More Coherent Water Resource Management Paradigm. Water Alternatives, 8 (1), 675-694.

Murphy, C.F. and Allen, D.T., 2011. Energy-Water Nexus for Mass Cultivation of Algae. Environmental Science \& Technology, 45 (13), 5861-5868.

MWE - Brandenburg Ministry of Economic and European Affairs, 2012. Energiestrategie 2030. Potsdam: Brandenburg Ministry of Economic and European Affairs.

Naturschutzbeirat beim Ministerium für Umwelt, Gesundheit und Verbraucherschutz des Landes Brandenburg, 2011. Stellungnahme zur Biomassestrategie des Landes Brandenburg vom August 2010. Eberswalde/Müncheberg: Naturschutzbeirat beim Ministerium für Umwelt, Gesundheit und Verbraucherschutz des Landes Brandenburg.

Naumann, M., 2014. Institutionelle Handlungszwänge und -möglichkeiten von Infrastruktursysteme der Abwasserentsorgung und Energieversorgung. In: T. Moss and B. Nölting, eds. Mehrschichtige Institutionenanalyse zum nachhaltigen Landmanagement. Chancen und Hemmnisse der Nutzung von gereinigtem Abwasser. Müncheberg: Leibniz Centre for Agricultural Landscape Research, 55-66.

Naumann, M. and Moss, T., 2012. Neukonfiguration regionaler Infrastrukturen. Chancen und Risiken neuer Kopplungen zwischen Energie- und Abwasserinfrastruktursystemen. Müncheberg: Leibniz Centre for Agricultural Landscape Research.

Naumann, M. and Reichert-Schick, A., 2013. Infrastructure and Peripheralization: Empirical Evidence from North-Eastern Germany. In: A. Fischer-Tahir and M. Naumann, eds. 
1 Peripheralization. The Making of Spatial Dependencies and Social Injustice. Wiesbaden:

2 Springer VS, 145-167.

3 Nölting, B., and Daedlow, K., 2012. Einblick in die Akteurslandschaft zum Wasser- und

4 Landmanagement in Brandenburg und Berlin - Am Beispiel der Stoffströme "geklärten

5 Abwassers" und "Magnesium-Ammonium-Phosphat-Dünger". Müncheberg: Leibniz Centre

6 for Agricultural Landscape Research.

7 Nölting, B., Balla, D., Daedlow, K., Grundmann, P., Oehlschläger, K., Maaß, O., Moss, T.,

8 Steinhardt, U. and Von Bock und Polach, C., 2015. Gereinigtes Abwasser in der Landschaft.

9 Ein Orientierungsrahmen für strategische Entscheidungsprozesse. Müncheberg: Leibniz

Centre for Agricultural Landscape Research.

Olsson, G., 2012. Water and Energy - Threats and Opportunities. London: IWA Publishing.

Perrone, D., Murphy, J., and Hornberger, G.M., 2011. Gaining Perspective on the WaterEnergy Nexus at the Community Scale. Environmental Science \& Technology, 45 (10), 4228 4234.

Pittcock, J., 2011. National Climate Change Policies and Sustainable Water Management: Conflicts and Synergies. Ecology and Society, 16 (2), 25.

Po, M., Kaercher, J., and Nancarrow B.E., 2004. Literature Review of Factors Influencing Public Perceptions of Water Reuse [online]. Available from: http://www.clw.csiro.au/publications/technical2003/tr54-03.pdf [Accessed 5 March 2015].

Schäfer, M., and Kröger, M., eds., 2015. Nachhaltiges Landmanagement auf ehemaligen Rieselfeldern. Rahmenbedingungen, Erfahrungen und Potenziale am Beispiel Wansdorf. Müncheberg: Leibniz Centre for Agricultural Landscape Research.

Schiffler, A., and Gansler, J., 2014. Regionale Strompreisunterschiede in Deutschland. Kurzgutachten. Leipzig: Leipziger Institut für Energie.

Schmidt-Walter, P., and Lamersdorf, N., 2012. Biomass Production with Willow and Poplar Short Rotation Coppices on Sensitive Areas - the Impact on Nitrate Leaching and Groundwater Recharge in a Drinking Water Catchment near Hanover, Germany. BioEnergy Research, 5 (3), $546-562$. 
1 Schmiedeskamp, C., 2011. Regelenergie aus virtuellen Kraftwerken - Chance für Betreiber von BHKW-Anlagen. Erhebliche Potenziale schlummern in Notstromaggregaten und KlärwerkBHKW. In: T.G. Schmitt, ed. Schriftenreihe des FG Siedlungswasserwirtschaft der Universität Kaiserslautern. Kaiserslautern: Technische Universität Kaiserslautern, 131-138.

Schwers, O., 2015. Versuchsanlage ohne Nutzung. Märkische Oderzeitung [online], 19 April. Available from: http://www.moz.de/artikel-ansicht/dg/0/1/1383950 [Accessed 1 July 2015]

Scott, C.A., Pierce, S.A., Pasqualetti, M.J., Jones, A.L., and Montz, B.E., 2011. Policy and Institutional Dimensions of the Water-Energy Nexus. Energy Policy, 39 (10), 6622-6630.

SenStadt and MUGV - Senate Department for Urban Development and Environment \& Brandenburg Ministry of Environment, Health and Consumer Protection, 2012. Reduzierung der Nährstoffbelastungen von Dahme, Spree und Havel in Berlin sowie der Unteren Havel in Brandenburg. Gemeinsames Handlungskonzept der Wasserwirtschaftsverwaltungen der Bundesländer Berlin und Brandenburg. Berlin/Potsdam: Senate Department for Urban Development and Environment and Brandenburg Ministry of Environment, Health and Consumer Protection.

Siddiqi, A. and Anadon, L.D., 2011. The water-energy nexus in Middle East and North Africa. Energy Policy, 39 (10), 4529-4540.

Stein, C., Barron, J., and Moss, T., 2014. Governance of the nexus: from buzz words to a strategic action perspective. Brighton: The Nexus Network.

Steinigeweg, S., 2012. Kommunale Kläranlagen als Energiespeicher. Projektbeschreibung [online]. Available from: http:/www.hs-emden-leer.de/forschung-

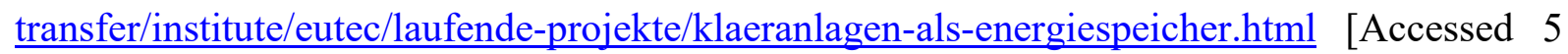
March 2015].

Stillwell, A., Hoppock, D., and Webber, M., 2010. Energy Recovery from Wastewater Treatment Plants in the United States: A Case Study of the Energy-Water Nexus. Sustainability, 2 (4), 945-962.

Urkiaga, A., de las Fuentes, L., Bis, B., Chiru, E., Balasz, B., and Hernández, F., 2008. Development of analysis tools for social, economic and ecological effects of water reuse. Desalination, 218 (1-3), 81-91. 
1 Van der Bruggen, B., 2010. The Global Water Recycling Situation. In: I. Escobar and A.

2 Schäfer, eds. Sustainable Water for the Future: Water Recycling versus Desalinaton.

3 Amsterdam et al.: Elsevier, 41-62.

4 Voß, R., Brandt, M., and Große, U., 2011. Wissenschaftliche Begleitung von Erprobungen nach

5 dem Brandenburgischen Standarderprobungsgesetz. Wildau: Technische Hochschule Wildau.

6 Wang, R., not dated. Water-Energy Nexus: A Critical Review Paper.

7 http://environment.yale.edu/hixon/files/Water-Energy\%20Nexus Ranran\%20Wang.pdf

$8 \quad$ [Accessed 21 April 2014].

9 Williams, J., Bouzarovski, S., and Swyngedouw, E., 2014. Politicising the nexus: Nexus 10 technologies, urban circulation, and the coproduction of water-energy. Brighton: The Nexus 11 Network.

12 Windolff, D., 2012. Dreister Eingriff in Forschungsprojekt. Märkische Oderzeitung [online], 23 October. Available from: http://www.moz.de/artikel-ansicht/dg/0/1/1043098 [Accessed 5 March 2015].

World Economic Forum, 2009. Energy vision update 2009. Thirsty energy: water and energy in the $21 \mathrm{st}$ century [online]. Available from:

http://www3.weforum.org/docs/WEF_WaterAndEnergy21stCentury_Report.pdf [Accessed 21 April 2014].

Zimmermann, R., 2001. Social Implications of Infrastructure Network Interactions. Journal of Urban Technology, 8(3), 97-119.

\section{Interviews}

Agriculture \# 1, 7 October 2011

Energy utility \# 1, 3 June 2013

Regional planning \# 1, 8 July 2011

Wastewater utility \# 1, 26 January 2012

Wastewater utility \# 2, 12 May 2012

Wastewater utility \# 3, 8 November 2011

Wastewater utility \# 4, 8 December 2011

Wastewater utility \# 5, 28 May 2013 
1 Water authority \# 1, 23 May 2011 